\author{
열충격 시험 후 태양전지 파괴 모드에 따른 전기적 특성변화 \\ 강민수 · 전유재 · 신영의 ${ }^{\dagger}$ \\ 중앙대학교 기계공학부 \\ (2013년 11월 16일 접수, 2013년 12월 18일 수정, 2013년 12월 18일 채택)
}

\title{
Electric Degradation of Failure Mode of Solar Cell by Thermal Shock Test
}

\author{
Kang Min-Soo $\cdot$ Jeon Yu-Jae $\cdot$ Shin Young-Eui \\ School of Mechanical Engineering, Chung-Ang University
}

(Received 16 November 2013, Revised 18 December 2013, Accepted 18 December 2013)

요 약

일본 연구에서는 열충격 시험을 통한 태양전지의 파괴모드에 따른 전기적 특성을 분석하였다. 시편은 Photovoltaic Module을 만들기 전 3 line Ribbon을 Tabbing한 단결정 Solar Cell을 제작하였다. 열충격 시험 Test 1 의 온도조건은 저온 $-40^{\circ} \mathrm{C}$, 고온 $85^{\circ} \mathrm{C}$, Test 2 는 저온 $-40^{\circ} \mathrm{C}$, 고온 $120^{\circ} \mathrm{C}$ 에서 Ramping Time을 포함하여 각각 15 분씩, 총 30 분을 1 사이클로 500 사이클을 각각의 조건으로 수행하였다. 열충 격 시험 후 Test 1 에서는 $4.0 \%$ 의 효율 감소율과 $1.5 \%$ 의 Fill Factor 감소율을 확인하였으며, Test 2 에 서는 $24.5 \%$ 의 효율 감소율과 $11.8 \%$ 의 Fill Factor 감소율을 확인하였다. EL(Electroluminescence)촬영 및 단면을 분석한 결과, Test 1 과 Test 2 시편 모두 Cell 표면 및 내부에서의 Crack이 발견되었다. 하지만, Test 2 의 시험이 Test 1 보다 가혹한 온도조건의 시험으로 인해 Test 1 에서 나타나지 않았던, Cell 파괴를 Test 2 에서 확인하였다. 결국, Test 1 에서 효율의 직접적인 감소 원인은 Cell 내부에서의 Crack이며, Test 2에서는 Cell 내부에서의 Crack 및 Cell 파괴로 인한 Cell 자체의 성능저하로 효율이 크게 감소한다는 것을 본 실험을 통하여 규명하였다.

주요어 : PV module, Bare Cell, EL, I-V, Fill Factor, Power drop, Fill Factor, Thermal shock test, Thermal Cycle test

\section{1. 서 론}

태양에너지는 무한한 에너지원으로 많은 관심을 받고 있으며, 연구 및 개발이 활발히 진행 중에 있다. 태양광 발전은 태양빛이 있는 한 계속해서 발전이 가 능하지만, 모듈의 면적에 비례하여 전력이 생산 되므 로 넓은 부지를 필요로 하게 된다. 또한, 계절에 따른 발전량의 차이가 큰 것이 단점으로 지적되고 있다.[1] 따라서, 많은 국가에서는 실리콘 태양전지의 효율을 높이고자 많은 노력을 기울이고 있으며, 현재 실험실

\footnotetext{
'To whom corresponding should be addressed. School of Mechanical Engineering, Chung-Ang University, Seoul 756-756, korea

Tel : 031-880-5435 E-mail : shinyoun@cau.ac.kr
}

수준의 결정질 실리콘 태양전지의 효율은 $24.7 \%$ 로써 호주 UNSW의 PERL Cell로 보고되고 있다. 이는 실 리콘 Band Gap에너지에 따른 이론한계 효율인 $28 \%$ 에 매우 근접한 수준이다.[2][3] 초기 태양전지의 높 은 효율 뿐 아니라, 경년 시 나타나는 태양광 모듈의 효율 감소 및 출력저하의 원인을 규명하고, 품질보증 을 할 수 있는 연구가 진행되어야 할 것이다.

국내·외에 가장 많이 사용되는 결정질 태양전지는 Fig. 1과 같이 Silicon Wafer에 전면전극을 형성한 후 태양광 Ribbon을 Tabbing 한 후 이를 외부 환경에 보호하기 위하여 강화유리 및 EVA(Ethylene Vinyl Acetate), Backsheet를 Laminating 공정을 통하여 PV 모듈(Photovoltaic Module)로 만든다.[4] 이렇게 제작 


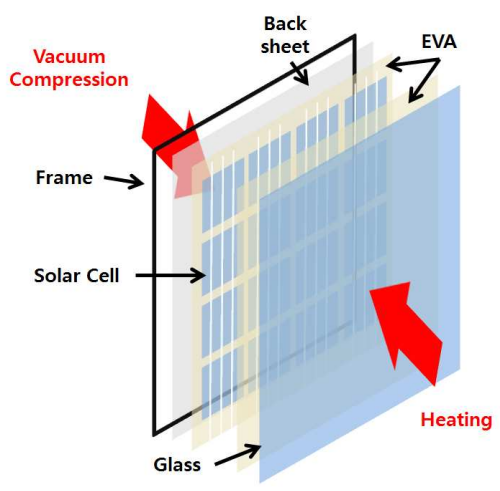

Fig. 1. Photovoltaic Module

된 PV 모듈은 옥외에 설치되어 열과 습기에 노출되 며, 외부 환경에 의한 노화현상이 발생한다. 태양광에 너지를 통하여 모아진 전자를 집진시키는 주 이동 통 로인 Solar Cell 표면의 Ribbon부는 복합재료의 접합 부이다. 이는 외부 열에 노출되면, Ribbon 접합부의 서로 다른 열팽창 계수차에 의해 취약해 질 수 있으 며, 이를 통하여 효율에 영향을 미칠 수 있다고 판단 된다. 따라서, 본 연구에서는 열충격 시험을 통하여 경년 시 나타나는 Solar Cell의 파괴 모드 및 전기적 특성변화를 고찰 하였다.

\section{2. 실험방법}

\section{2-1. 실험시편}

태양전지 Ribbon접합부의 신뢰성 평가를 위해 Fig. 2와 같이 Silicon Wafer에 Ag Paste로 3개의 전면전 극과 Gridfinger을 형성하고, 3 개의 전면전극위에 태 양광 Ribbon을 접합한 Solar Cell을 시편으로 제작하 였다. 일반적인 6인치 단결정(Single Crystalline) Cell 로 가로, 세로 $156 \mathrm{~mm}$ 의 면적은 $238.95 \mathrm{~cm}^{2}$ 이다.

\section{2-2. 열충격 시험}

옥외 설치된 $\mathrm{PV}$ 모듈이 받는 표면 온도는 설치된 장소나 통풍 조건에 따라 큰 차이가 있다. 겨울철에 도 직사광선 하에서 표면온도가 $25^{\circ} \mathrm{C}$ 이상이 유지되 며, 여름철의 경우 표면온도가 $70^{\circ} \mathrm{C}$ 내외로 상승한다 고, 보고되고 있다.[5] 따라서, $\mathrm{PV}$ 모듈에서의 평가규 격인 KS C IEC 61215[6]의 온도 사이클 시험을 인 용하여 Table 1 과 같이 Test 1 의 시험 조건을 설정 하였으며, 추가적인 Test 2 의 시험 조건은 Test 1 보다 가혹한 조건에서 수행하였다. 열충격 시험 온도프로

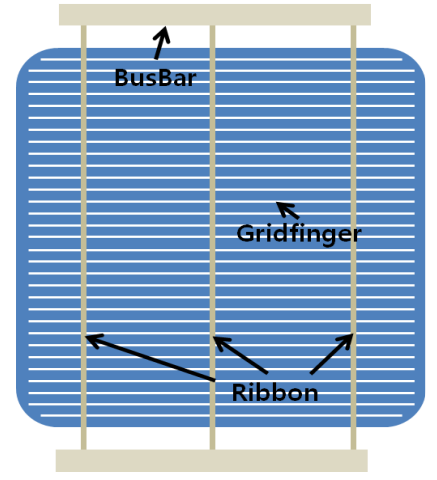

Fig. 2. Specimens of Solar Cell

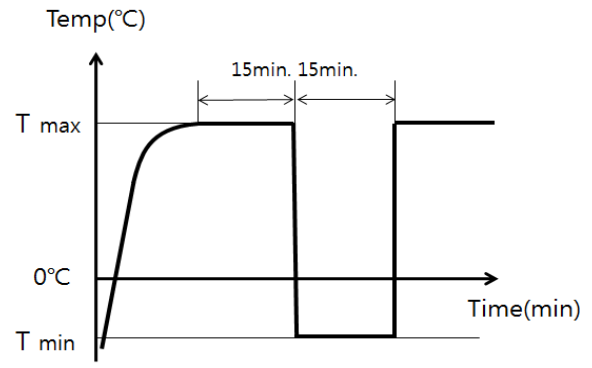

Fig. 3. Temperature profile of Thermal Shock Test

Table 1. Condition of Thermal Shock Test

\begin{tabular}{c|c|c|c|c}
\hline Test & Tmin & Tmax & Time & Cycle \\
\hline \hline Test 1 & $-40^{\circ} \mathrm{C}$ & $85^{\circ} \mathrm{C}$ & $30 \mathrm{~min}$ & 500 \\
\hline Test 2 & $-40^{\circ} \mathrm{C}$ & $120^{\circ} \mathrm{C}$ & $30 \mathrm{~min}$ & 500 \\
\hline
\end{tabular}

파일은 Fig. 3에 나타내었다.

2-3. EL 및 $\mathrm{I}-\mathrm{V}$ 특성곡선

열충격 시험 전·후를 비교분석하기 위하여 $\mathrm{EL}$ (Electroluminescence)ㅊㅊㄹ영 및 $\mathrm{I}-\mathrm{V}$ 특성 곡선을 측 정하였다. $\mathrm{EL}$ 촬영은 태양전지에 전류를 인가하여 태 양전지가 내는 빛을 촬영한 사진이다. 열충격 시험 전·후 Cell 표면의 음영변화를 통하여 Cell의 균열 및 Gridfinger의 손상 유·무를 분석할 수 있다. 또한, I-V 특성곡선은 태양전지에 표준시험 조건의(STC : Standard Test Condition 입사조도: $1000 \mathrm{~W} / \mathrm{m}$ 태양전 지 온도: $25^{\circ} \mathrm{C}$ 대기질량(AM): 1.5 의 상태) 일사량을 


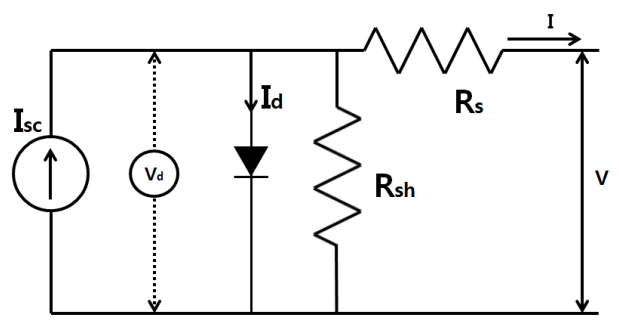

Fig. 4. Equivalent Circuit of Solar Cell
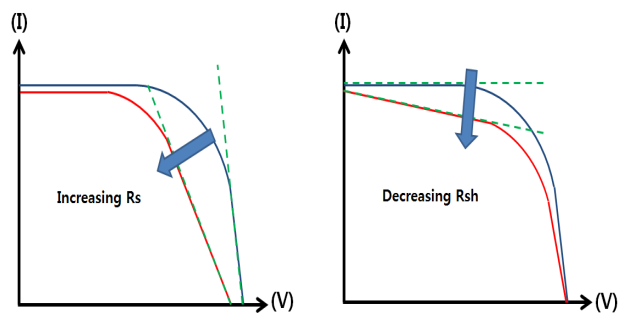

(a) Increasing $R_{S}$

(b) Decreasing $R_{S H}$

Fig. 5. I-V Curve according to Resistance of variation

주어 개방전압 $\left(V_{\text {ideal }}\right)$, 단락전류 $\left(I_{\text {ideal }}\right)$, 최대출력전 압 $\left(V_{\max }\right)$, 전류 $\left(I_{\max }\right)$, 최대출력전력 $\left(P_{\max }\right)$, 효율 (\%), 곡선율(Fill Factor :FF)을 측정하는 기법으로 태양전지의 효율 및 전기적 특성 변화를 분석할 수 있으며, I-V특성곡선을 통하여 태양전지의 저항 변 화를 확인 할 수 있다.

Fig. 4의 태양전지 등가회로도와 같이 태양전지의 저항은 직렬저항 $\left(R_{s}\right)$ 과 병렬저항 $\left(R_{s h}\right)$ 으로 구분할 수 있다. $R_{s}$ 는 Cell 외부손상에 의한 저항에 해당하며, $R_{s h}$ 는 Cell 자체의 누설전류 및 Shunt저항에 해당한 다. 따라서, 이상적인 Cell의 경우 $R_{s}$ 저항은 " 0 ", $R_{s h}$ 저항은 “ $\infty$ ”값으로 전류가 흐를 수 있는 다른 통 로를 제공하지 않게 된다. 하지만, 실제 Cell에서는 경년 및 외부환경에 따른 직·병렬 저항의 변화가 발 생하여 전기적 특성이 변하게 된다.

또한, Fig. 5 와 같이 $R_{s h}$ 의 감소는 전류곡선의 시 작부터 기울기가 변하게 되며, $R_{s}$ 의 증가는 전류곡선 의 끝 부분의 기울기가 변하게 된다.[3][7]

\section{3. 결과 및 고찰}

\section{3-1. 효율 및 Fill Factor 변화}

Table 2. Degradation of Efficiency \& Fill Factor after Test

\begin{tabular}{c|c|c}
\hline & Test 1 & Test 2 \\
\hline \hline 시험 전 효율 & $15.0 \%$ & $13.9 \%$ \\
\hline 시험 후 효율 & $14.4 \%$ & $10.5 \%$ \\
\hline 효율 감소율 & $4.0 \%$ & $24.5 \%$ \\
\hline 시험 전 $\mathrm{FF}$ & $73.2 \%$ & $70.3 \%$ \\
\hline 시험 후 $\mathrm{FF}$ & $72.1 \%$ & $62.0 \%$ \\
\hline $\mathrm{FF}$ 감소율 & $1.5 \%$ & $11.8 \%$ \\
\hline
\end{tabular}

Table 2의 열충격 시험 전·후 효율을 확인한 결과, Test 1 의 시편은 열충격 시험 전 $15.0 \%$ 에서 열충격 시험 후 $14.4 \%$ 로 효율이 감소하였으며, 효율 감소율 은 $4.0 \%$ 임을 확인하였다. Test 2 의 시편은 $13.9 \%$ 에 서 $10.5 \%$ 로 효율이 감소하여, $24.5 \%$ 의 높은 감소율 을 확인하였다.

Test 1 시편의 FF 변화는 열충격 시험 전 $73.2 \%$ 에서 열충격 시험 후 $72.1 \%$ 로 감소하여, $\mathrm{FF}$ 감소율 은 $1.5 \%$ 임을 확인하였으며, Test 2 의 시편은 $70.3 \%$ 에서 $62.0 \%$ 로 $\mathrm{FF}$ 감소율은 $11.8 \%$ 임을 확인하였다. 열충격 시험 후 Test 1,2 시편에서의 효율 감소 및 $\mathrm{FF}$ 감소의 원인을 규명하기 위하여 Cell 표면 및 단 면을 관찰하였다.

\section{3-2. 표면 및 단면관찰}

열충격 시험 후 Test 1 시편의 표면을 관찰한 결 과, Fig. 6에서와 같이 Ribbon 접합부의 표면 손상은 확인할 수 없었다. 하지만, Test 2 의 시편은 열충격 시험 후 Fig. 7(a)과 같이 Ribbon접합부 끝부터 Ribbon이 떨어지는 현상을 확인하였다. Ribbon이 떨 어진 접합부를 Fig. 7(b)와 같이 확대하여 관찰한 결 과, Ribbon접합부의 Cell이 파괴되는 것을 확인하였 다. Cell의 전체적인 손상을 관찰하기 위하여 $\mathrm{EL}$ 촬영 을 통한 표면 및 단면을 분석하였다.

Fig. 8(b), (2)와 같은 Cell Crack은 이종재료 ( $\mathrm{Sn}-\mathrm{Pb}, \mathrm{Ag}$ paste, Ribbon)간의 열응력차에 의하여 Cell이 파괴되기 전에 나타나는 현상으로 판단된다. Fig 8(b), (3)에 나타난 손상은 Fig. 9(a)와 같이 Ribbon접합부 Cell 내부에서의 우측 Crack에 의해 나타난 음영이라 판단된다. Fig. 8(b), (4)에서 나타난 손상 또한, Fig. 9(b)를 통하여 Ribbon접합부 Cell 내 부에서의 우측 Crack으로 확인하였다. 하지만, Fig. 


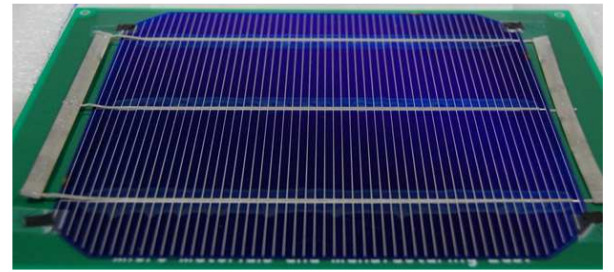

(a) Appearance of Cell

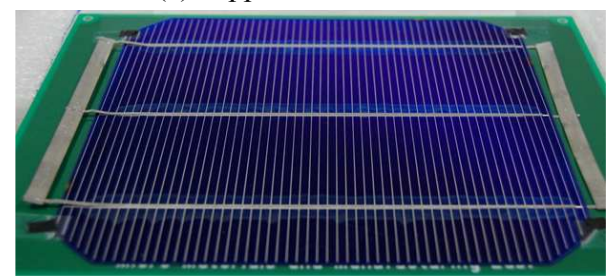

(b) Solar Ribbon after Test (X25)

Fig. 6. Condition of Test 1

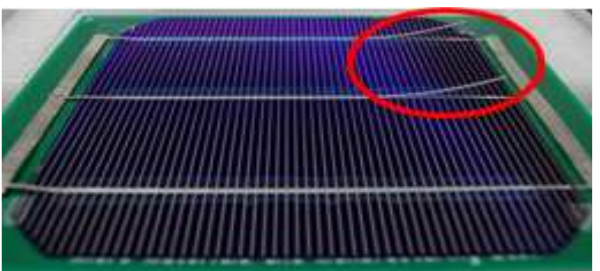

(a) Appearance of Cell

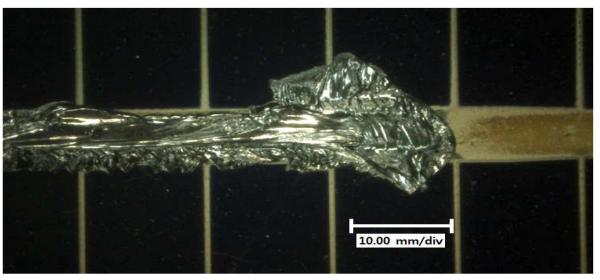

(b) Solar Ribbon after Test (X25)

Fig. 7. Condition of Test 2

8(b), (3)과 (4) 표면에서의 음영 변화가 다르게 나타났 다. 이는 한쪽 방향의 내부 Crack에 의해 Gridfinger 가 손상 됐지만, 손상되지 않은 다른 방향의 Gridfinger로 전류가 흐를 수 있어 Fig. 8(b), (3)과 같 은 음영의 변화가 나타난 것이며, Fig. 8(b), (4)에서 나타난 현상은 Fig. 9(b)에서와 같이 한쪽 방향의 내 부 Crack이지만, Ribbon의 위치 특성상 전류가 돌아 갈 수 있는 이동통로를 제공하지 못하여 $\mathrm{EL}$ 촬영 시 Black Sector를 형성했다고 판단된다.[8]

Fig. 10(b), (1)에서와 같이 Black Sector가 먼저 형 성되고, Cell Crack이 나타난 결과는, Fig. 7(a)와 같 이 Cell이 파괴되어 Ribbon이 떨어지는 과정에서 생 긴 Cell Crack이다. Fig. 10(b), (2)에서 나타난 손상 은 Fig. 11(a)에 나타낸 내부 Crack으로, Fig 8(b), (3)

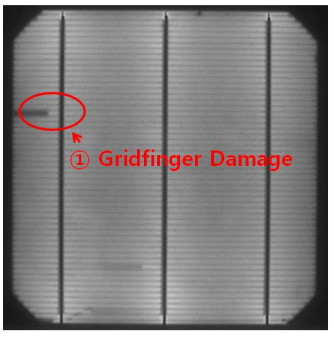

(a) Appearance of Cell

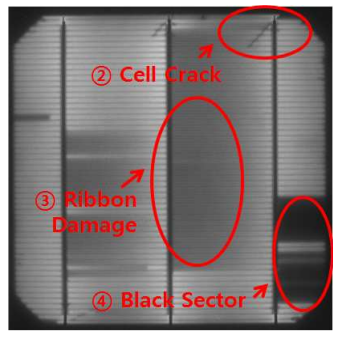

(b) 500 Cycle
Fig. 8. EL Image of Test 1

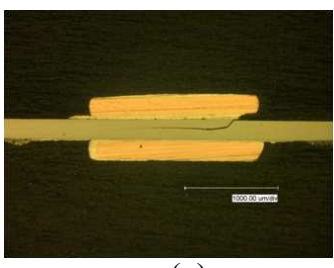

(a)

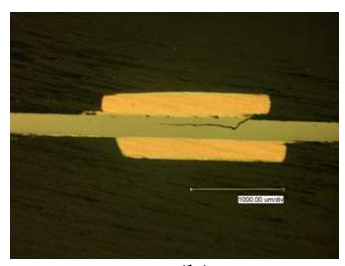

(b)
Fig. 9. Cross-section Image of Test 1

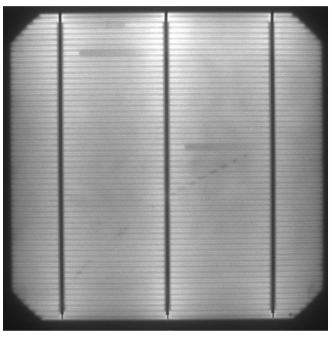

(a) Appearance of Cell

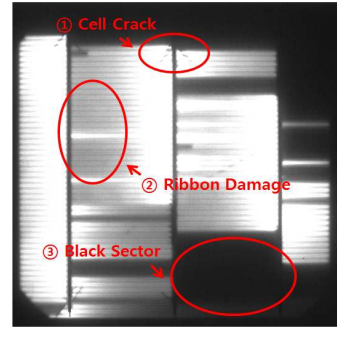

(b) 500 Cycle
Fig. 10. EL Image of Test 2

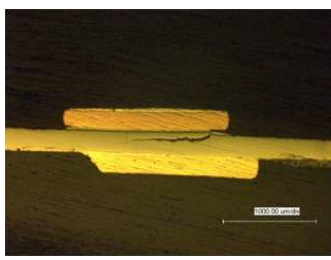

(a)

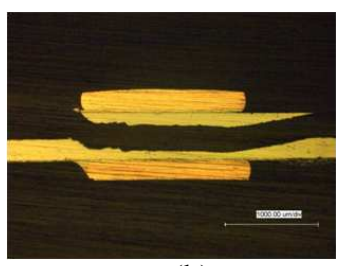

(b)
Fig. 11. Cross-section Image of Test 2

과 같은 음영이 나타났으며, Fig. 10(b), (3)과 같은 Black Sector는 Fig. 11(b)의 단면 사진과 같은 Cell 내부에서의 파괴로 전류가 흐를 수 없어 형성되었다.

Fig. 8과 Fig. 10을 통하여 열충격 시험 후 Cell 표면의 손상을 확인하였으며, Test 2의 시험이 Test 1 보다 가혹한 온도조건의 시험으로 인하여 Test 1에 서 나타나지 않았던, Cell 파괴가 Test 2에서는 나타 나는 것을 확인하였다. 이로 인해 Test 1에서의 


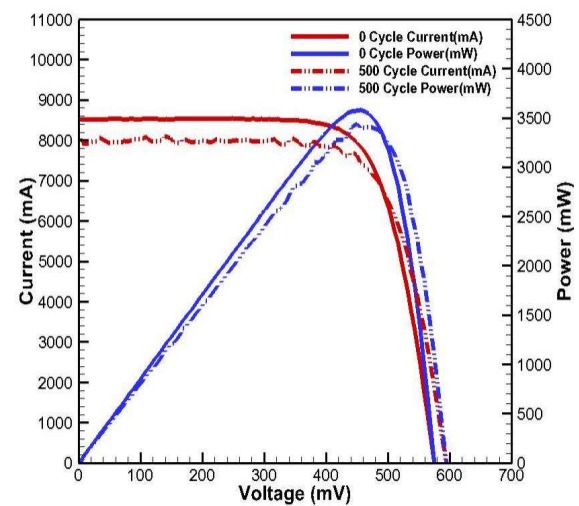

Fig. 12. I-V Characteristic Curve after Test 1

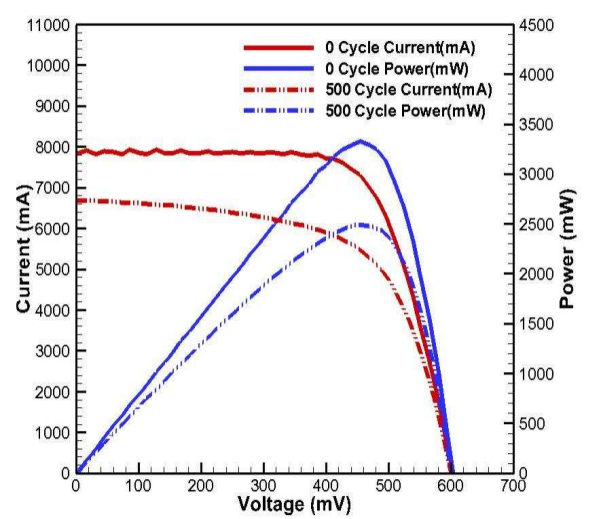

Fig. 13. I-V Characteristic Curve after Test 2

Black Sector 면적보다 Test 2에서 크게 나타나는 것 으로 판단된다.

Cell 손상에 따른 전기적 특성 변화를 분석하기 위 하여 열충격 시험 전.후 I-V 특성곡선을 비교 분석하 였다.

\section{3-3. 전기적 특성분석}

Fig. 12에 나타낸 Test 1 의 I-V 특성곡선을 분석한 결과, 열충격 시험 후 개방전압 $\left(V_{\text {ideal }}\right)$ 은 증가하였으 며, 단락전류 $\left(I_{i d e a l}\right)$ 는 감소한 것을 확인하였다. 그래 프 특성상 I-V 측정 시 온도 편차에 의한 변화[9][10] 라 판단되지만, 표면 및 단면 분석을 통하여 Cell 내 부 $\mathrm{Crack}$ 에 의한 출력전력 $\left(P_{\mathrm{max}}\right)$ 의 감소임을 확인하 였다. 또한, 열충격 시험 후 $\operatorname{Current}\left(I_{\max }\right)$ 가 낮아져 Current 곡선이 열충격 시험 전보다 아래에 위치해 있을 뿐, Fig. 5(a)와 같이 Current 곡선의 기울기가 초기에 형성 되지 않았으며, 효율 감소율 $(4.0 \%)$ 대비
$\mathrm{FF}$ 감소율( $1.5 \%)$ 이 작게 나타난 것을 감안 한다면, 외부 환경에 의한 Cell 내부 Crack에 의해 전자의 수 가 줄어들고, 전류의 세기에 영향을 주어 직렬저항을 증가시킨 것으로 판단된다.

Fig. 13에 나타낸 Test 2 시편의 I-V 특성곡선은 열충격 시험 후 개방전압의 변화는 확인할 수 없었으 나, 단락전류가 크게 감소하는 결과를 나타냈다. 이와 같은 결과는 Cell 내부에서의 파괴가 Cell 표면의 Black Sector를 형성하고, 전자가 이동할 수 없게 되 어, 단락전류가 크게 감소한 것으로 판단된다. 또한, Current 곡선의 시작부터 기울기 변화를 확인하였다. 이는 Fig. 5(b)와 같은 유사한 Current 곡선의 기울기 를 가지며, 병렬저항이 감소하였다는 것을 확인할 수 있었다. 결국, Cell 내부에서의 파괴는 Cell 표면의 Black Sector의 형성 뿐 아니라, $\mathrm{p}-\mathrm{n}$ 층의 손상을 가져 왔으며, 이로 인하여 출력전력 $\left(P_{\max }\right)$ 에 큰 영향을 주어 효율이 감소한 것이다.

이와 같은 결과를 통하여 열충격 시험 후 Test 1 에 서의 직접적인 효율의 감소 원인은 Cell 내부의 Crack으로 인한 Gridfinger의 단선으로 효율을 감소 시켰으며, Test 2에서는 Cell 내부에서의 Crack으로 인한 Gridfinger의 단선 및 Cell 파괴로 인한 Black Sector 형성, $\mathrm{p}-\mathrm{n}$ 층 손상으로 인한 Cell 자체의 성능 이 저하되어 효율이 크게 감소한다는 것을 본 실험을 통하여 규명하였다.

향후, Cell을 보호하는 EVA, Glass 등이 Cell에 미치는 영향을 정량적으로 분석해야 할 것이며, 역 바이어스 $\mathrm{I}-\mathrm{V}$ 측정을 통해 병렬저항의 변화 및 직렬 저항의 변화를 비교하여 Cell 내부 저항과 Ribbon접 합부의 손상을 정량적으로 분석해야 할 것이다.

\section{4. 결 론}

열충격 시험을 통한 태양전지의 파괴모드에 따른 전기적 특성을 분석하여 다음과 같은 결론을 얻었다.

(1) 열충격 시험 후 Test $1\left(-40^{\circ} \mathrm{C} \sim 85^{\circ} \mathrm{C}\right)$ 의 시편에 서는 Cell 표면 및 내부에서의 Crack을 확인하 였다.

(2) 열충격 시험 후 Test $2\left(-40^{\circ} \mathrm{C} \sim 120^{\circ} \mathrm{C}\right)$ 의 시편 에서는 Cell 표면 및 내부에서의 Crack과 Cell 파괴를 확인하였다.

(3) Cell 내부의 Crack은 음영의 변화를 가져왔으 
며, 직렬저항을 증가시켜 효율감소에 영향을 준 것으로 확인하였다.

(4) Cell 내부의 파괴는 Black Sector를 형성하고, $\mathrm{p}-\mathrm{n}$ 전극을 손상시켜, 병렬저항의 감소로 인한 Cell 자체의 성능저하가 효율감소에 직접적인 영향을 준 것으로 본 실험을 통하여 규명하였 다.

\section{참고문헌}

1. Seong-Geol Kim, Chang-Woo Hong, and Kyung-Sup Lee, "Analysis of the Electrical Properties of Solar Cell According to Variation of the Frequency", J. KIEEME Vol. 25, No. 5, pp. 372-376, May 2012

2. Sung Ju Tark, Young Do Kim, Soo Min Kim, Sungeun Park and Donghwan Kim, "Light Induced Degradation in Crystalline Si Solar Cells", New \& Renewable Energy 2012. 3 Vol. 8, No. 1

3. Augustin McEvoy, Tom Markcart, Luis Castaner, "Practical handbook of Photovoltaics Fundamentals and Applications", ACADEMIC PRESS, pp7-19, pp67-75

4. Kang Min-Soo, Kim Do-Seok, Jeon Yu-Jae, Shin Young-Eui, "The Study on Thermal Shock Test Characteristics of Solar Cell for Long-term Reliability Test", Journal of Energy Engineering, Vol. 21, No. 1, pp. 26 32 (2012).

5. 박종화 著, “알기쉬운 태양광발전”, 문운당, pp80-82.

6. KS C IEC 61215 , 결정질 실리콘 지상용 태양 전지 모듈-설계인증 및 형식승인.

7. Erees Queen B. Macabebe, Charles J. Sheppard, E. Ernest van Dyk, "Parameter extraction from I?V characteristics of PV devices", Solar Energy, Volume 85, Issue 1, January 2011, Pages 12-18.

8. M.A. Munoz, M.C. Alonso-Garc?a, Nieves Vela, F. "Early degradation of silicon PV modules and guaranty conditions ", Chenlo, Solar Energy, Volume 85, Issue 9, September
2011, Pages 2264-2274

9. Babita Guptaa, P.K. Shishodiaa, A. Kapoora, R.M. Mehraa, Tetsuo Sogab, Takashi Jimbob, Masayoshi Umeno, "Effect of illumination intensity and temperature on the I2V characteristics of $\mathrm{n}-\mathrm{C} / \mathrm{p}-\mathrm{Si}$ heterojunction", Solar Energy Materials and Solar Cells, Volume 73, Issue 3, July 2002, Pages 261-267

10. Manjunatha Pattabi, Sheeja Krishnan, Ganesh Sanjeev, "Studies on the temperature dependence of I?V and C?V characteristics of electron irradiated silicon photo-detectors", Solar Energy Materials and Solar Cells, Volume 91, Issues 15?16, 22 September 2007, Pages 1521-1524 